\title{
Plant Growth Promoting Rhizobacteria Having 1-Aminocyclopropane-1-Carboxylic Acid Deaminase to Induce Salt Tolerance in Sunflower (Helianthus annus L.)
}

\author{
Muhammad Zahid Kiani1 ${ }^{*}$, Arshad Ali2, Tariq Sultan², Rizwan Ahmad², Syed Ishtiaq Hydar² \\ ${ }^{1}$ PARC Institute of Advanced Studies in Agriculture, Islamabad, Pakistan \\ ${ }^{2}$ Land Resources Research Institute, National Agricultural Research Center, Islamabad, Pakistan \\ Email: zahidkiani55@gmail.com
}

Received 1 May 2015; accepted 7 June 2015; published 11 June 2015

Copyright (C) 2015 by authors and Scientific Research Publishing Inc.

This work is licensed under the Creative Commons Attribution International License (CC BY). http://creativecommons.org/licenses/by/4.0/

(c) (i) Open Access

\section{Abstract}

Soil salinity badly affects agriculture productivity through accumulation of salts in upper layers of soils. The harmful effects of salts in arable lands have influenced modern as well as ancient civilizations. A pot study was carried out to test the performance of two PGPR isolates (KS 8, KS 28) on sunflower (SMH-0917) under different salinity levels $\left(8,10\right.$ and $\left.12 \mathrm{dS} \cdot \mathrm{m}^{-1}\right)$. These salinity levels were developed by adding calculated amount of salts $\left(\mathrm{NaCl}, \mathrm{Na}_{2} \mathrm{SO}_{4}, \mathrm{CaCl}_{2}\right.$ and $\left.\mathrm{MgSO}_{4}\right)$ with ratio of 3:4:2:1. The bacterial strains KS 8 and KS 28 were applied separately in two treatments while third treatment was co-inoculation (KS mix). Completely randomized experimental design (CRD) was used and data were collected at flowering stage about pre-decided plant growth parameters (plant height, shoot dry weight and root dry weight). The bacterial isolate KS 8 showed an increase of $26,102 \%$ and $83 \%$ in plant height, shoot dry weight and root dry weight at EC $8 \mathrm{dS} \cdot \mathrm{m}^{-1}$, while this improvement was $67 \%, 163 \%$ and $296 \%$ at EC $10 \mathrm{dS} \cdot \mathrm{m}^{-1}$, however an increase of $100 \%, 74 \%$ and $382 \%$ was recorded over control respectively at EC $12 \mathrm{dS} \cdot \mathrm{m}^{-1}$. Similarly isolate KS 28 exhibited an increase of $14 \%, 69 \%$ and $54 \%$ in plant height; shoot dry weight and root dry weight at EC $8 \mathrm{dS} \cdot \mathrm{m}^{-1}$, whereas this improvement was $56 \%, 163 \%$ and $188 \%$ at EC $10 \mathrm{dS} \cdot \mathrm{m}^{-1}$, while an increase of $60 \%, 41 \%$ and $282 \%$ was registered respectively over control at EC $12 \mathrm{dS} \cdot \mathrm{m}^{-1}$. The increase due to mixture treatments was $4 \%, 41 \%$ and $16 \%$ in plant height, shoot dry weight and root dry weight at EC $8 \mathrm{dS} \cdot \mathrm{m}^{-1}$, while an increase of $33 \%, 57 \%$ and $100 \%$ at EC $10 \mathrm{dS} \cdot \mathrm{m}^{-1}$, whereas an improvement of $53 \%, 33 \%$ and $164 \%$ respectively was noted at EC $12 \mathrm{dS} \cdot \mathrm{m}^{-1}$ over un-inoculated. The isolate KS 8 performed better than KS 28 and mixture treatment. These two PGPR strains could be used to mitigate the adverse impact caused by salinity stress on sunflower.

\footnotetext{
*Corresponding author.
}

How to cite this paper: Kiani, M.Z., Ali, A., Sultan, T., Ahmad, R. and Hydar, S.I. (2015) Plant Growth Promoting Rhizobacteria Having 1-Aminocyclopropane-1-Carboxylic Acid Deaminase to Induce Salt Tolerance in Sunflower (Helianthus annus L.). Natural Resources, 6, 391-397. http://dx.doi.org/10.4236/nr.2015.66037 


\section{Keywords}

\section{Plant Growth Promoting Rhizobacteria, Strains, 1-Aminocyclopropane-1-Carboxylic Acid (ACC) Deaminase, Salinity}

\section{Introduction}

Sunflower (Helianthus annus L.) belongs to plant kingdom Plantae and family Asteraceae. It is native to America and good source of edible oil throughout the world because of low cholesterol. Its seed contains $47.5 \%$ oil which is ranked next to peanuts $48.5 \%$. Pakistan produces only $18 \%$ edible oil of its consumption and remaining 82\% are being imported. In 2012-2013 Rs 153.3 billion (US \$1.595 billion) was spent on import of edible oil and oil seed for extraction of oil [1]. Pakistan is third largest importer of edible oil in the world. Its import bill is the largest drain on national exchequer and second to mineral oil [2].

Environmentally safe and sustainable agriculture production is one of the major problems faced by the agriculture of $21^{\text {st }}$ century. It is increasing demand in agriculture for sound and ecologically compatible strategies. Agriculture is a natural process and more related to natural activities. The world population is increasing and agricultural land is decreasing. The challenge is to increase soil productivity with minimal changes to environment.

It is high time to bring 6.28 million hectares of salt affected area of Pakistan into arable farming to cater the need of food for growing population [3]. According to an estimate twenty percent (20\%) agriculture lands are affected by salinity at world level [4]. The loss of productive land as a result of alkalinity and salinity is a direct clash with requirement of providing food supplies to the global population. Many efforts are made to increase crop productivity under salinity stress but have not proven completely fruitful, because the basic mechanism of salinity stress is not completely known up till now.

In the recent past many researchers have focused on the performance of plant growth promoting rhizobacteria (PGPR) having ACC deaminase activity to mitigate the negative impact of enhanced level of ethylene caused by salinity stress. This pot study was also carried out to induce salts tolerance in sunflower through PGPR. PGPR have diverse mechanism through which support plant growth, like atmospheric nitrogen fixation, solubilization of mineral phosphorus, siderophores production, mineralization of other nutrients, anti pathogenic affect and also has ability to produce IAA, etc. [5]-[7].

\section{Materials and Methods}

Thirty-six strains were isolated from five samples, collected from different salt-affected areas of Punjab (Pakis$\tan )$. The biochemical characterization was carried out on the basis of ACC deaminase activity and solubilization of inorganic phosphorus. Two promising bacterial strains (KS28, KS 8) having highly level of ACC deaminase enzyme as compared to others were selected for this green house pot study. After harvesting potassium and sodium contents in plant samples were determined by suing the method as reported [8], and phosphorus content of plant was measured by using method as explained [9].

\subsection{Inoculum Preparation}

These strains were inoculated in aflask of $200 \mathrm{~mL}$ volume containing LB broth media and thenincubated in shaker at $28^{\circ} \mathrm{C} \pm 2^{\circ} \mathrm{C}$ three to four days. These cultures were shifted to biofertilizer carrier (soil high in organic matter). Hybrid sunflower seed (SMH-0917) were surface sterilized before inoculating with slurry which was prepared by mixing of $10 \%$ sugar solution in raw material of biofertilizer.

\subsection{Pot Study}

The green house of national agriculture research center (NARC), Islamabad (Pakistan) was selected for pot study. The soil used were analyzed for physio-chemicals properties and characterized as sandy clay loam, having $\mathrm{pH} 7.89$, ECe $1.0 \mathrm{dS} \cdot \mathrm{m}^{-1}$, organic matter $0.80 \%$, phosphorus $4.52 \mathrm{mg} \cdot \mathrm{kg}^{-1}$, potassium $4.22 \mathrm{meq} \cdot \mathrm{L}^{-1}$, calcium and magnesium $6.21 \mathrm{meq} \cdot \mathrm{L}^{-1}$ and saturation percentage $31.5 \%$. Measured amount of different salts $\left(\mathrm{NaCl}, \mathrm{Na}_{2}\right.$ 
$\mathrm{SO}_{4}, \mathrm{CaCl}_{2}$ and $\mathrm{MgSO}_{4}$ ) with ratio of 3:4:2:1 were used to develop three salinity levels 8, 10, $12 \mathrm{dS} \cdot \mathrm{m}^{-1}[10]$. The soil samples were taken from different pots of each repeat to determine EC levels through EC meter. Thirty six pots were filled with autoclaved soil; each pot contained five $\mathrm{kg}$ of soil. Recommended dose of fertilizer (100-60-50) were applied. Whole of phosphorus and potash were mixed in soil whereas nitrogenous fertilizer was applied in two split doses. Theses pots in green house were placed according to completely randomized experimental design (CRD) with three replications. Plants were harvested at flowering stage and data about predecided growth parameters (plant height, root dry weight and shoot dry weight) were recorded. Data were analyzed by the analysis of variance (ANOVA) and treatment mean comparison by using least significance difference (LSD; $\mathrm{P}=0.05$ ) [11]. The analyses were conducted using the software statistic 8.1.

\section{Results}

The data collected on plant height showed that bacterial strains (KS 8 and KS28) significantly increased plant height as compared to un-inoculated at all salinity levels. The isolate KS 8 showed an increase of $26 \%, 67 \%$ and $100 \%$ as compared to control whereas isolate KS 28 exhibited an increase of $14 \%, 56 \%$ and $60 \%$ at 8, 10 and 12 $\mathrm{dS} \cdot \mathrm{m}^{-1}$ respectively over control. However mixture treatment (KS mix) recorded significant improvement (33\% and 53\%) only at salinity levels 10 and $12 \mathrm{dS} \cdot \mathrm{m}^{-1}$ respectively as compared to control (Table 1 ).

As regards root dry weight, improvement was also recorded over control at all salinity levels. The bacterial strain KS 8 exhibited an increase of $83 \%, 296 \%$ and $382 \%$ as compared to un-inoculated, whereas isolate KS 28 showed an improvement of $54 \%, 188 \%$ and $282 \%$ at 8,10 and $12 \mathrm{dS} \cdot \mathrm{m}^{-1}$ respectively over control. While mixture treatment showed an increase of $16 \%, 100 \%$ and $164 \%$ at EC 8,10 and $12 \mathrm{dS} \cdot \mathrm{m}^{-1}$ respectively over control (Table 2).

Like plant height PGPR inoculation (KS 8 and KS 28) significantly increased shoot dry weight at all salinity levels. This increase was 102\%, 163\% and 74\% over control, while KS 28 showed an improvement of $69 \%$, $163 \%$ and $41 \%$ at EC 8,10 and $12 \mathrm{dS} \cdot \mathrm{m}^{-1}$ respectively over un-inoculated. Whereas incase of mixture treatment an increase of $47 \%, 57 \%$ and $33 \%$ was recorded at salinity levels 8,10 and $12 \mathrm{dS} \cdot \mathrm{m}^{-1}$ respectively over control. Among tested treatments bacterial strain KS 8 perform better at all salinity levels followed by KS28 respectively (Table 3).

\section{Discussion}

Higher salts concentration on outer side of plants have a direct effect on cell growth and associative metabolism, osmotic effect is immediate while accumulation of salts with in plant body up to toxic level take time i.e. from

Table 1. Effect of PGPR inoculation on sunflower plant height $(\mathrm{cm})$ at four salinity levels (data presented is of three replicates).

\begin{tabular}{cccc}
\hline Strain & $\mathbf{8 ~ d S} \cdot \mathbf{m}^{\mathbf{- 1}}$ & $\mathbf{1 0} \mathbf{d S} \cdot \mathbf{m}^{\mathbf{- 1}}$ & $\mathbf{1 2} \mathbf{~ d S} \cdot \mathbf{m}^{\mathbf{- 1}}$ \\
\hline Control & $38 \mathrm{e}$ & $30 \mathrm{f}$ & $30 \mathrm{f}$ \\
KS 8 & $48 \mathrm{bc}$ & $50 \mathrm{~b}$ & $60 \mathrm{a}$ \\
KS 28 & $45 \mathrm{~d}$ & $47 \mathrm{~cd}$ & $48 \mathrm{bc}$ \\
KS mix & $40 \mathrm{e}$ & $40 \mathrm{e}$ & $46 \mathrm{~cd}$ \\
\hline
\end{tabular}

Means having similar letters don't differ statistically from each other at $\mathrm{P} \leq 0.05$.

Table 2. Effect of PGPR inoculation on sunflower root dry weight (g) plant ${ }^{-1}$ at four salinity levels (data presented is of three replicates).

\begin{tabular}{|c|c|c|c|}
\hline Strain & $8 \mathrm{dS} \cdot \mathrm{m}^{-1}$ & $10 \mathrm{dS} \cdot \mathrm{m}^{-1}$ & $12 \mathrm{dS} \cdot \mathrm{m}^{-1}$ \\
\hline Control & $0.46 \mathrm{f}$ & $0.26 \mathrm{~h}$ & $0.22 \mathrm{~h}$ \\
\hline KS 8 & $0.84 \mathrm{c}$ & $1.03 \mathrm{~b}$ & $1.06 \mathrm{a}$ \\
\hline KS 28 & $0.71 \mathrm{de}$ & $0.75 \mathrm{~cd}$ & $0.62 \mathrm{e}$ \\
\hline KS mix & $0.52 \mathrm{f}$ & $0.52 \mathrm{f}$ & $0.36 \mathrm{~g}$ \\
\hline
\end{tabular}

Means having similar letters don't differ statistically from each other at $\mathrm{P} \leq 0.05$. 
hours to days [12].

Salinity stress increase ethylene level in root rhizosphere and affect negatively first seed germination and then root and shoot length. The inoculation of seed with such PGPR having ACC-deaminase decrease ethylene level by hydrolyzing ACC into ammonia a ketobutyrate in rhizospheric region and improve plant growth [18]. Plant early growth stage is more sensitive as compared to later stages so inoculation with bacteria having ability to mitigate salinity stress can be helpful for plants to overcome from stress [13]-[15]. Different researchers have also reported that PGPR inoculation also improved seed germination under salinity stress [16]-[18]. Salinity stress increase ethylene level and inhibit plant root and proliferation [19]-[22], as in case of control, whereas inoculation with bacteria having ACC deaminase decrease ethylene level induced by high salts concentration and help to elevate the salinity stress on root and plant growth and in response to this reduced level of ethylene, plant perform better as exhibited by inoculated plants. For better plant growth and root proliferation any control on this enhanced level of ethylene is necessary [23]-[25]. Our results are also in line with the finding of [26] [27], on groundnut and wheat crops.

A similar trend in plant growth parameters were reported [28]. They conducted a pot experiment on wheat at four salinity levels 1.46, 5, 10 and $15 \mathrm{dS} \cdot \mathrm{m}^{-1}$ and found significant increased in plant growth at 10 and 15 $\mathrm{dS} \cdot \mathrm{m}^{-1}$ over un-inoculated with PGPR strains W17 and W2 having ACC deaminase activity. Less sodium and more potassium uptake is important characteristic of salinity tolerant plants. Plants having higher $\mathrm{K}^{+} / \mathrm{Na}^{+}$ratio are considered as more salt tolerant plants [29] [30]. In our study all PGPR inoculated treatments recorded higher $\mathrm{K}^{+} / \mathrm{Na}^{+}$ratio as compared to control at all salinity levels (Table 4). The exact mechanism by which bacterial isolates regulate uptake of these ions is not completely known. But it is think this might be due to better root proliferation or exopolysaccharide activity of bacteria (ability to bind sodium and thus decrease its availability for uptake) [31] [32].

In this study two bacterial isolates (KS 8 and KS 28) having ACC deaminase were tested in a pot trial. Inoculation of sunflower seed with these bacterial strains significantly increased plant height and root dry weight at 12 $\mathrm{dS} \cdot \mathrm{m}^{-1}$ followed by $10 \mathrm{dS} \cdot \mathrm{m}^{-1}$ over control (Figures 1-3).

This improvement in root length and root weight is because of inoculation with PGPR strains having higher level of ACC deaminase activity as compared to other strains (ACC deaminase quantification data is not presented here).

Table 3. Effect of PGPR inoculation on sunflower shoot dry weight (g) plant ${ }^{-1}$ at four salinity levels (data presented is of three replicates).

\begin{tabular}{cccc}
\hline Strain & $\mathbf{8 ~ d S} \cdot \mathbf{m}^{-\mathbf{1}}$ & $\mathbf{1 0 ~} \mathbf{~ d S} \cdot \mathbf{m}^{-\mathbf{1}}$ & $\mathbf{1 2} \mathbf{~ d S} \cdot \mathbf{m}^{\mathbf{- 1}}$ \\
\hline Control & $4.8 \mathrm{f}$ & $3.5 \mathrm{~h}$ & $3.0 \mathrm{i}$ \\
KS 8 & $9.7 \mathrm{a}$ & $9.2 \mathrm{~b}$ & $4.25 \mathrm{fg}$ \\
KS 28 & $8.1 \mathrm{c}$ & $9.2 \mathrm{~b}$ & $4.25 \mathrm{fg}$ \\
KS mix & $7.0 \mathrm{~d}$ & $5.5 \mathrm{e}$ & $4.20 \mathrm{~g}$ \\
\hline
\end{tabular}

Means having similar letters don’t differ statistically from each other at $\mathrm{P} \leq 0.05$.

Table 4. Effect of PGPR inoculations on phosphorus, potassium contents (\%) and $\mathrm{K}^{+} / \mathrm{Na}^{+}$ratio in shoot of sunflower (60 days old) under different salinity levels.

\begin{tabular}{|c|c|c|c|c|c|c|c|c|c|}
\hline \multirow{3}{*}{ Strains } & \multirow{2}{*}{\multicolumn{3}{|c|}{$\begin{array}{c}\text { Phosphorus (\%) } \\
\text { Salinity level }\left(\mathrm{dS} \cdot \mathrm{m}^{-1}\right)\end{array}$}} & \multicolumn{3}{|c|}{ Potassium (\%) } & \multicolumn{3}{|c|}{$\mathrm{K}^{+} / \mathrm{Na}^{+}$ratio } \\
\hline & & & & \multicolumn{3}{|c|}{ Salinity level $\left(\mathrm{dS} \cdot \mathrm{m}^{-1}\right)$} & \multicolumn{3}{|c|}{ Salinity level $\left(\mathrm{dS} \cdot \mathrm{m}^{-1}\right)$} \\
\hline & 8 & 10 & 12 & 8 & 10 & 12 & 8 & 10 & 12 \\
\hline Control & 0.27 ghi & $0.20 \mathrm{jk}$ & $0.09 \mathrm{l}$ & 2.75 ghi & $2.39 \mathrm{hi}$ & $2.25 \mathrm{i}$ & $4.23 \mathrm{f}$ & $3.57 \mathrm{f}$ & $3 \mathrm{~d}$ \\
\hline KS 8 & $0.70 \mathrm{c}$ & $0.58 \mathrm{~d}$ & 0.27 ghi & $4.79 \mathrm{bc}$ & $4.73 \mathrm{bc}$ & 4.06 fghi & $6.94 \mathrm{~d}$ & $6.31 \mathrm{~b}$ & $3.73 \mathrm{c}$ \\
\hline KS 28 & $0.60 \mathrm{~d}$ & 0.40 ghi & 0.25 hij & $4.44 \mathrm{~cd}$ & 4.26 cde & 4.11 cdef & 8.22 а & 6.98 a & 3.69 e \\
\hline KS mix & $0.57 \mathrm{de}$ & 0.40 ghi & 0.24 hij & 4.07 cdef & 3.89 cdef & 4.03 cdef & $7.40 \mathrm{c}$ & $5.81 \mathrm{c}$ & $5.23 \mathrm{a}$ \\
\hline
\end{tabular}

Means having similar letter(s) in a column do not differ significantly at $\mathrm{P} \leq 0.05$. 
Un-inoculated $\quad$ KS $8 \quad$ KS $28 \quad \square$ KS mix

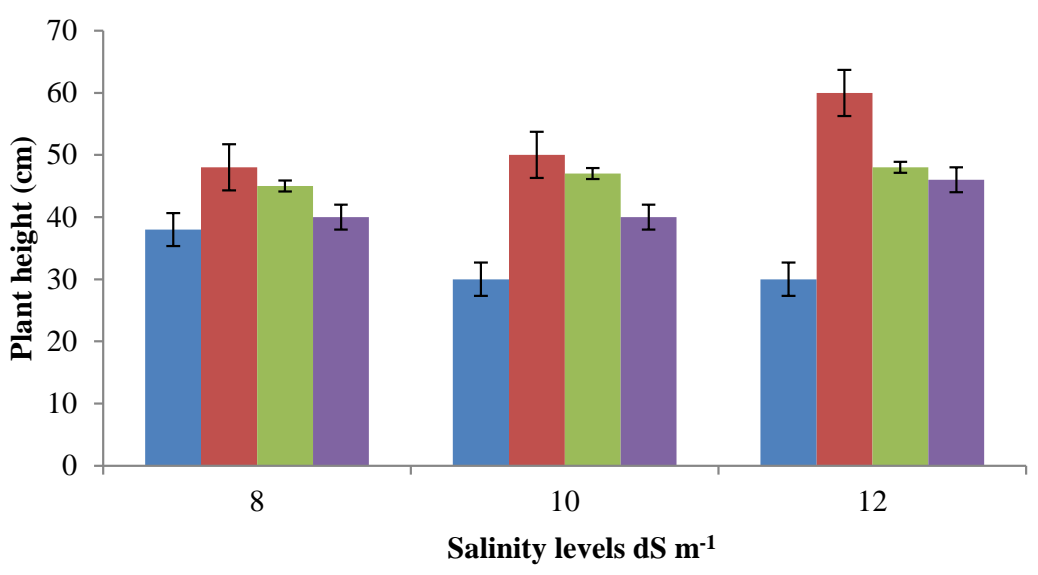

Figure 1. Percent increase in root length over respective control at different salinity levels.

- Un-inoculated $\quad$ KS $8 \quad$ KS $28 \quad \square$ KS mix

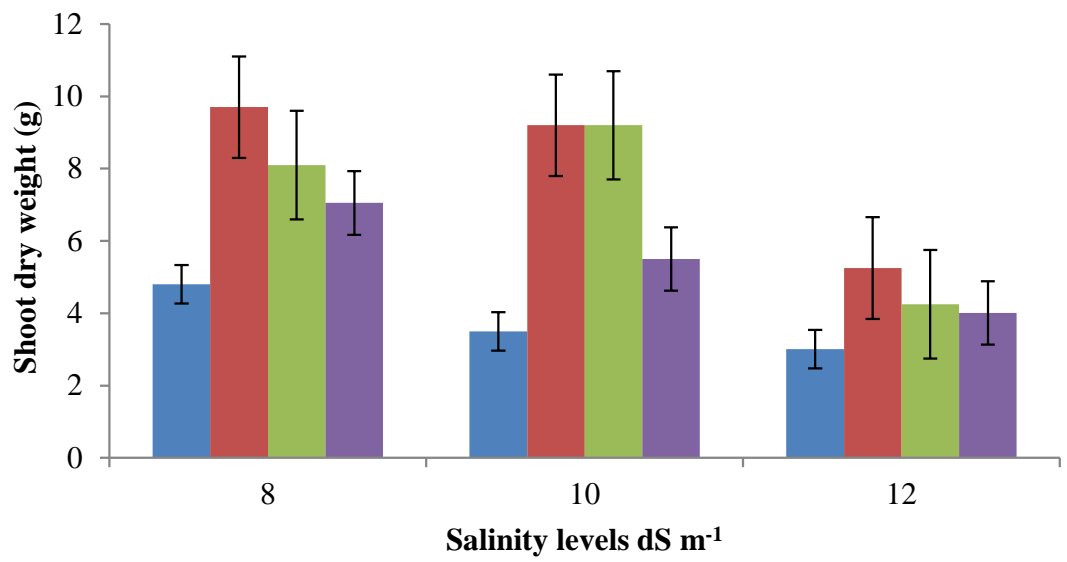

Figure 2. Percent increase in shoot dry weight over respective control at different salinity levels.

$$
\text { -Un-inoculated } \quad \text { KS } 8 \quad \text { KS } 28 \quad \text { KS mix }
$$

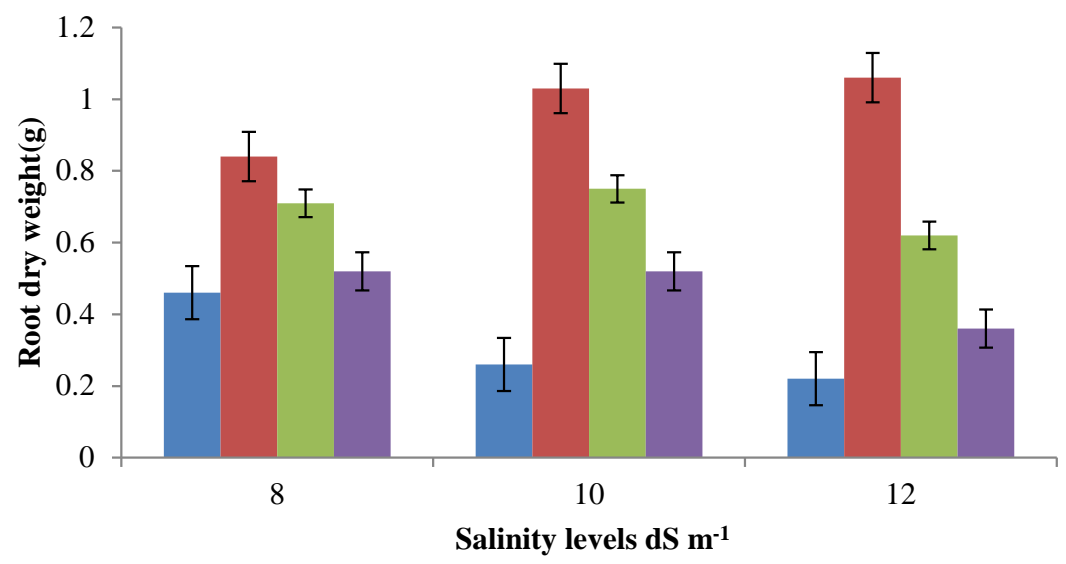

Figure 3. Percent increase in root dry weight over respective control at different salinity levels. 


\section{Conclusion}

In this screening study two PGPR isolates were tested in three treatments (KS 8, KS 28 and KS mix) at three different salinity levels $\left(8,10,12 \mathrm{dS} \cdot \mathrm{m}^{-1}\right)$ against their control (un-inoculated). The sunflower plants inoculated with bacterial isolate KS 8 conformed better growth in term of plant height, shoot dry weight and root dry weight as compared to isolate KS 28. The performance of mixture treatment was below as compared to separate inoculation of isolates KS 8 and KS 28. This might be due to non-compatible combination of these strains with each other. Further testing of these strains should be carried out at different salinity levels under field conditions.

\section{References}

[1] GOP, 2012-2013. Government of Pakistan Ministry of Finance Statistic Division.

[2] Siddiqui (2010) Nutrient Management for Sunflower Production. Ph.D. Dissertation Tendo Jam University of Sindh, Pakistan.

[3] Ghafoor, A., Qadir, M. and Murtaza, G. (2004) Salt Affected Soils: Principal of Management. Allied Book Centre, Urdu Bazar, Lahore, 304.

[4] Yeo, A.R. (1999) Predicting the Interaction between the Effects of Salinity and Climate Change on Crop Plants. SciHortic (Amsterdam), 78, 159-174. http://dx.doi.org/10.1016/S0304-4238(98)00193-9

[5] Glick, B.R. (1995) The Enhancement of Plant Growth by Free-Living Bacteria. Canadian Journal of Microbiology, 41, 109-117. http://dx.doi.org/10.1139/m95-015

[6] Glick, B.R., Patten, C.L., Holguin, G. and Penrose, D.M. (1999) Biochemical and Genetic Mechanisms Used by Plant Growth-Promoting Bacteria. Imperial College Press, London, 267.

[7] US Salinity Laboratory Staff (1954) Diagnosis and Improvement of Saline and Alkali Soils. Agric. Handbk. 60. US Government Printing Office, Washington DC.

[8] Ryan, J., Estenfan, G. and Rashid, A. (2001) Soil and Plant Analysis Laboartary Manual. Internal Center for Agricultural Research in the Dry Areas (ICARDA), Aleppo, 172pp.

[9] Wright, R.J. and Stuczynski, T.I. (1996) Atomic Absorption and Flame Emission Spectrometry. In: Sparks, D.L., et al., Eds., Methods of Soil Analysis. Part-III: Chemical Methods. Soil Science Society of America, Madison, 65-90.

[10] Richard, L.A. (1954) Diagnosis and Improvement of Saline and Alkai Soils. US Department of Agriculture, Washington DC.

[11] Steel, R.G.D., Torrie, J.H. and Dickey, D.A. (1997) Principles and Procedures of Statistics: A Biometrical Approach. 3rd Edition, McGraw Hill, Inc. Book Co., New York, 352-358.

[12] Munas, R. and Testar, M. (2008) Mechanism of Salinity Tolerance. Annual Review of Plant Biology, 59, 651-681. http://dx.doi.org/10.1146/annurev.arplant.59.032607.092911

[13] Nadeem, S.M., Zahir, Z.A., Naveed, M., Asghar, H.N. and Arshad, M. (2010) Rhizobacteria Capable of Producing ACC-Deaminase May Mitigate Salt Stress in Wheat. Soil Science Society of America Journal, 74, 533-542. http://dx.doi.org/10.2136/sssaj2008.0240

[14] Foolad, M.R. (2000) Genetic Basis of Salt Tolerance and Cold Tolerance in Tomato. Current Opinion in Plant Biology, 2, 35-49.

[15] Sallam, H.A. (1999) Effect of Some Seed-Soaking Treatments on Growth and Chemical Components on Faba Bean Plants under Saline Conditions. Annals of Agricultural Sciences, 44, 159-171.

[16] Ashraf, M., Zafar, R. and Ashraf, M.Y. (2003) Time-Course Changes in the Inorganic and Organic Components of Germinating Sunflower Achenes under Salt (NaCl) Stress. Flora, 198, 26-36. http://dx.doi.org/10.1078/0367-2530-00073

[17] Nelson, L.M. (2004) Plant Growth Promoting Rhizobacteria (PGPR): Prospects for New Inoculants. Crop Management, 10, 301-305.

[18] Barassi, C.A., Ayrault, G., Creus, C.M., Sueldo, R.J. and Sobrero, M.T. (2006) Seed Inoculation with Azospirillum mitigates $\mathrm{NaCl}$ Effects on Lettuce. Scientia Horticulturae, 109, 8-14. http://dx.doi.org/10.1016/j.scienta.2006.02.025

[19] Mishra, M., Kumar, U., Mishra, P.K. and Prakash, V. (2010) Efficiency of Plant Growth Promoting Rhizobacteria for the Enhancement of Cicer arietinum L. Growth and Germination under Salinity. Advances in Biological Research, 4, 92-96.

[20] Ashraf, M. (1994) Breeding for Salinity Tolerance in Plants. Critical Review Plant Sciences, 13, 17-17. http://dx.doi.org/10.1080/07352689409701906

[21] Marschner, H. (1995) Mineral Nutrition of Higher Plants. Academic Press, London. 
[22] Glick, B.R., Liu, C., Ghosh, S. and Dumbroff, E.B. (1997) Early Development of Canola Seedlings in the Presence of the Plant Growth-Promoting Rhizobacterium Pseudomonas putida GR12-2. Soil Biology and Biochemistry, 29, 12331239. http://dx.doi.org/10.1016/S0038-0717(97)00026-6

[23] Sarim, R.K. and Tyagi, A. (2004) Physiology and Molecular Biology of Salinity Stress Tolerance in Plants. Current Sciences, 86, 407-421.

[24] Mayak, S., Tirosh, T. and Glick, B.R. (2004) Plant Growth Promoting Bacteria Confer Resistance in Tomato Plants to Salt Stress. Plant Physiology and Biochemistry, 42, 565-572. http://dx.doi.org/10.1016/j.plaphy.2004.05.009

[25] Saleem, M., Arshad, M., Hussain, S. and Bhatti, A.S. (2007) Prospectus of Plant Growth Promoting Rhizobacteria (PGPR) Containing ACC Deaminase in Stress Agriculture. Journal of industrial Microbiology and Biotechnology, 34, 635-648. http://dx.doi.org/10.1007/s10295-007-0240-6

[26] Saravanakumar, D. and Samiyappan, R. (2007) ACC Deaminase from Pseudomonas fluorescens Mediated Saline Resistance in Groundnut (Arachis hypogea) Plants. Journal of Applied Microbiology, 102, 1283-1292. http://dx.doi.org/10.1111/j.1365-2672.2006.03179.x

[27] Nadeem, S.M., Zahir, Z.A., Naveed, M. and Nawas, S. (2013) Mitigation of Salinity-Induced Negative Impact on the Growth and Yield of Wheat by Plant Growth Promoting Rhizobacteria in Naturally Saline Conditions. Annals of Microbiology, 63, 225-232. http://dx.doi.org/10.1007/s13213-012-0465-0

[28] Greenway, H. and Munns, R. (1980) Mechanism of Salt Tolerance in Nonhalophytes. Annual Review Plant Physiology, 31, 149-190. http://dx.doi.org/10.1146/annurev.pp.31.060180.001053

[29] Jeschke, W.D. (1984) $\mathrm{K}^{+} \mathrm{Na}^{+}$Exchange at Cellular Membranes, Intercellular Compartmentation of Cations and Salt Tolerance. In: Staples, R.C., Ed., Salinity Tolerance in Plants: Strategies for Crop Improvement, John Wiley \& Sons, Chichester, 37-66.

[30] Ashraf, M., Hasnain, S., Berge, O. and Mahmood, T. (2004) Inoculating Wheat Seedling with ExopolysaccharideProducing Bacteria Restricts Sodium Uptake and Stimulates Plant Growth under Salt Stress. Biology and Fertility of Soils, 40, 157-162. http://dx.doi.org/10.1007/s00374-004-0766-y

[31] Kohler, J., Caravaca, F., Carrasco, L. and Roldan, A. (2006) Contribution of Pseudomonas mendocina and Glomus intraradices to Aggregate Stabilization and Promotion of Biological Fertility in Rhizosphere Soil of Lettuce Plants under Field Conditions. Soil Use Management, 22, 298-304. http://dx.doi.org/10.1111/j.1475-2743.2006.00041.x

[32] Nadeem, S.M., Zahir, Z.A., Naveed, M. and Arshad, M. (2009) Rhizobacteria Containing ACC Deaminase Confer Salt Tolerance in Maize Grown on Salt-Affected Fields. Canadian Journal of Microbiology, 55, 1302-1309. http://dx.doi.org/10.1139/W09-092 